\title{
Diversity of Bacterial Biota in Capnodis tenebrionis (Coleoptera: Buprestidae) Larvae
}

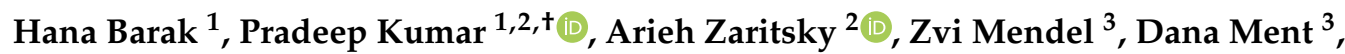 \\ Ariel Kushmaro ${ }^{1,4}$ (D) and Eitan Ben-Dov ${ }^{1,5, *}$
}

1 Avram and Stella Goldstein-Goren Department of Biotechnology Engineering, Ben-Gurion University of the Negev, P.O. Box 653, Beer-Sheva 8410501, Israel; hanare@post.bgu.ac.il (H.B.); pkbiotech@gmail.com (P.K.); arielkus@bgu.ac.il (A.K.)

2 Faculty of Natural Sciences, Ben-Gurion University of the Negev, P.O. Box 653, Beer-Sheva 8410501, Israel; ariehzar@gmail.com

3 Department of Entomology, Agricultural Research Organization, The Volcani Center, Rishon LeZion 7505101, Israel; zmendel@volcani.agri.gov.il (Z.M.); danam@volcani.agri.gov.il (D.M.)

4 National Institute for Biotechnology in the Negev, Ben-Gurion University of the Negev, Beer-Sheva 8410501, Israel

5 Department of Life Sciences, Achva Academic College, M.P. Shikmim Arugot 7980400, Israel

* Correspondence: etn@bgu.ac.il; Tel.: +972-74-7795317

+ Present Address: Department of Forestry, North Eastern Regional Institute of Science and Technology, Nirjuli 791109, Arunachal Pradesh, India.

Received: 2 December 2018; Accepted: 4 January 2019; Published: 6 January 2019

\begin{abstract}
The bacterial biota in larvae of Capnodis tenebrionis, a serious pest of cultivated stone-fruit trees in the West Palearctic, was revealed for the first time using the MiSeq platform. The core bacterial community remained the same in neonates whether upon hatching or grown on peach plants or an artificial diet, suggesting that $C$. tenebrionis larvae acquire much of their bacterial biome from the parent adult. Reads affiliated with class levels Gammaproteobacteria and Alphaproteobacteria (phylum Proteobacteria ca. $86 \%$ ), and Actinobacteria (ca. 14\%) were highly abundant. Most diverse reads belong to the families Xanthomonadaceae (50\%), Methylobacteriaceae (20\%), Hyphomicrobiaceae (9\%), Micrococcaceae (7\%) and Geodermatophilaceae (4.5\%). About two-thirds of the reads are affiliated with the genera Lysobacter, Microvirga, Methylobacterium, and Arthrobacter, which encompass species displaying cellulolytic and lipolytic activities. This study provides a foundation for future studies to elucidate the roles of bacterial biota in C. tenebrionis.
\end{abstract}

Keywords: bacterial biota; Buprestidae; Capnodis; stonefruit

\section{Introduction}

Insect pests may pose significant challenges to environmental quality and human welfare [1], but contribution of their symbiotic microorganisms for establishment and cause additional environmental and economic injury is still vague [2]. Multispecies microbial communities harbored in insect guts are involved in nutrition, digestion, and defense activities. Little is known about the diversity, physiology, and ecology of microorganisms associated with bark and wood-boring beetles $[3,4]$. Insect-symbiotic bacteria supplement essential nutrients, degrade complex dietary polymers and plant toxins [5-7], and thus contribute to overcoming plant defenses and higher host fitness [8,9]. Flatheaded borers Capnodis spp. (Coleoptera: Buprestidae) inflict serious harm to fruit and ornamental trees around the Mediterranean, in Southern Europe and in Western Asia [10]. Control regimes of Capnodis spp. populations rely on intensive applications of synthetic insecticides, whereas environmentally friendly means are partially absent. Capnodis tenebrionis is the most notorious 
pest among the congeners. Revealing the bacterial biota in larvae may be an avenue to the development of new, safe tools to cope with this pest. Information about microorganisms harbored by $C$. tenebrionis larvae does not exist; studying their core microbiota can improve the ability to develop more effective management approaches for this pest [11].

\section{Results and Discussion}

The number of reads per sample that passed a set of sequence filters range from 106,249 to 144,439 , with lengths of about $495 \mathrm{bp}$. The rarefaction analysis allowed for a comparison of species richness (number of OTUs) between different larvae and a determination of adequacy of sequencing output for each feeding regime. All rarefaction curves show the same slope and reach the plateau with 30,000 reads per sample (Figure 1 ).

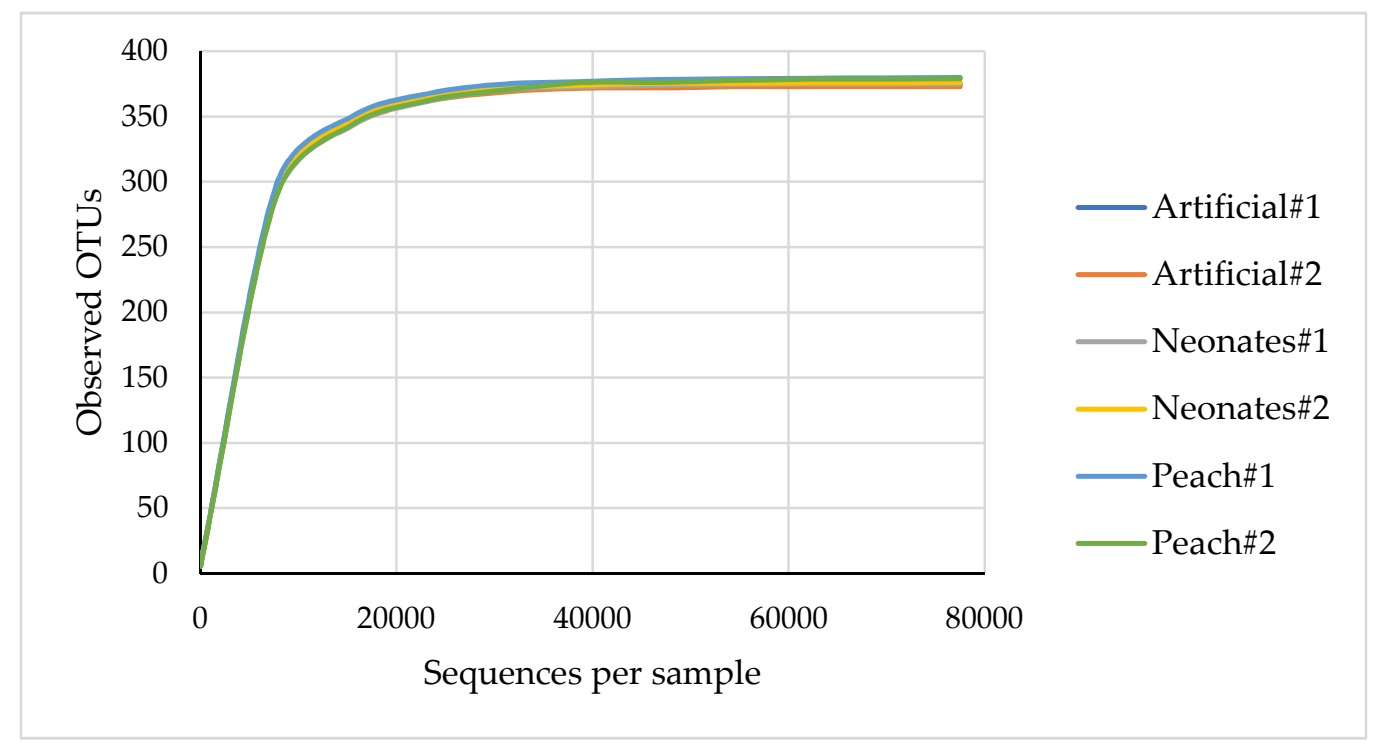

Figure 1. Rarefaction curves represent observed OTUs from C. tenebrionis under different feeding regimes.

The unweighted and weighted UniFrac phylogenetic distance metric plots, obtained using a principal coordinate analysis (PCoA), allowed for an assessment of microbial community differences between larvae of $C$. tenebrionis, neonates, and those grown on either peach plants or an artificial diet (Figure 2). The unweighted UniFrac distances (Figure 2A) show that compositions of these samples were identical, but the weighted distances (Figure 2B) display a variance in the communities' composition that is unexplained by diet type. Thus, diet type seems not to affect the bacterial biota composition of $C$. tenebrionis larvae. In other species, larval diet does affect the microbiota composition [6,12]. The pine weevil beetle Hylobius abietis is, however, also resilient to changes in diet [9]: their microbiome is the same whether they were fed on an artificial diet or on Norway spruce twigs. 


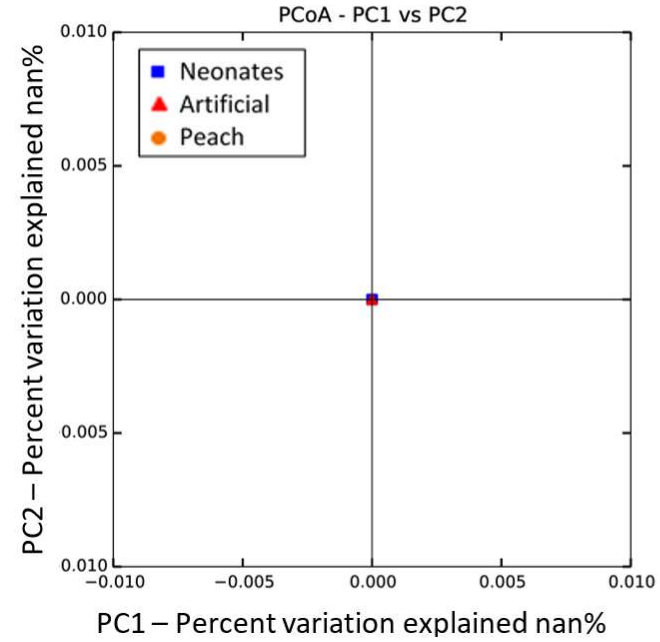

(A)

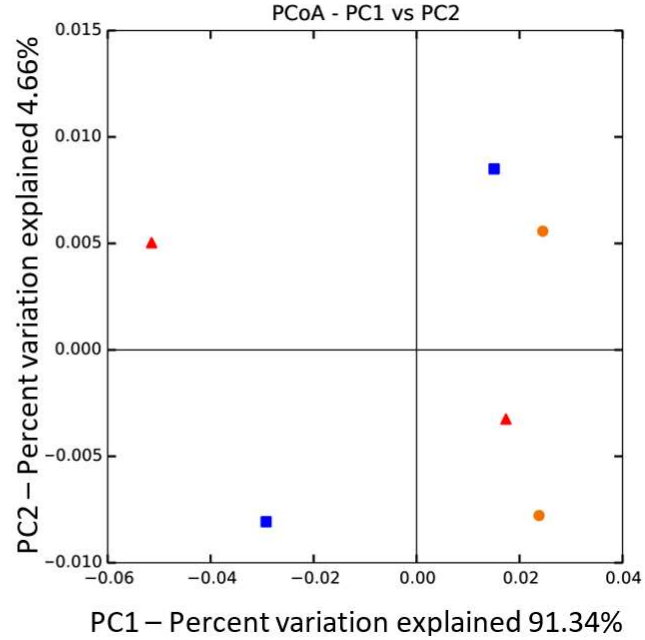

(B)

Figure 2. Bacterial community structures of larvae that grew on peach plants or an artificial diet, and in neonates. (A) UniFrac-unweighted principal coordinate analysis and (B) UniFrac-weighted principal coordinate analysis.

Most abundant reads in all $C$. tenebrionis larvae were affiliated with phyla of Proteobacteria (84-87\%) and Actinobacteria (12-15\%) (Figure 3; Table 1). At the class level, they were assigned to Gammaproteobacteria (46-52\%), Alphaproteobacteria (32-39\%), and Actinobacteria (12-15\%) (Figure 3; Table 2).

Table 1. Taxonomy assignment at the phylum level of $C$. tenebrionis on different feeding regimes.

\begin{tabular}{ccccccc}
\hline Phylum & Artificial\#1 & Artificial\#2 & Neonates\#1 & Neonates\#2 & Peach\#1 & Peach\#2 \\
\hline Proteobacteria & $87.22 \%$ & $85.12 \%$ & $86.60 \%$ & $85.21 \%$ & $83.86 \%$ & $84.69 \%$ \\
Actinobacteria & $12.09 \%$ & $14.25 \%$ & $12.83 \%$ & $14.23 \%$ & $15.38 \%$ & $14.85 \%$ \\
Unassigned & $0.54 \%$ & $0.56 \%$ & $0.49 \%$ & $0.37 \%$ & $0.42 \%$ & $0.35 \%$ \\
Others ${ }^{1}$ & $0.15 \%$ & $0.07 \%$ & $0.08 \%$ & $0.18 \%$ & $0.34 \%$ & $0.11 \%$ \\
\hline
\end{tabular}

${ }^{1}$ Others $=$ Bacteroidetes, Chloroflexi, Firmicutes, Planctomycetes, Cyanobacteria.

Table 2. Taxonomy assignment at the class level of $C$. tenebrionis on different feeding regimes.

\begin{tabular}{ccccccc}
\hline Class & Artificial\#1 & Artificial\#2 & Neonates\#1 & Neonates\#2 & Peach\#1 & Peach\#2 \\
\hline Gammaproteobacteria & $47.69 \%$ & $50.47 \%$ & $46.49 \%$ & $51.49 \%$ & $49.67 \%$ & $52.31 \%$ \\
Alphaproteobacteria & $39.13 \%$ & $33.80 \%$ & $39.65 \%$ & $33.28 \%$ & $33.79 \%$ & $31.88 \%$ \\
Actinobacteria & $12.07 \%$ & $14.23 \%$ & $12.79 \%$ & $14.21 \%$ & $15.35 \%$ & $14.83 \%$ \\
Unassigned $_{\text {Others }^{1}}$ & $0.54 \%$ & $0.56 \%$ & $0.49 \%$ & $0.37 \%$ & $0.42 \%$ & $0.35 \%$ \\
\hline
\end{tabular}

1 Others = Betaproteobacteria, Cytophagia, Acidimicrobiia, Thermomicrobia, Bacilli, Phycisphaerae, Chloroplast, Flavobacteriia. 


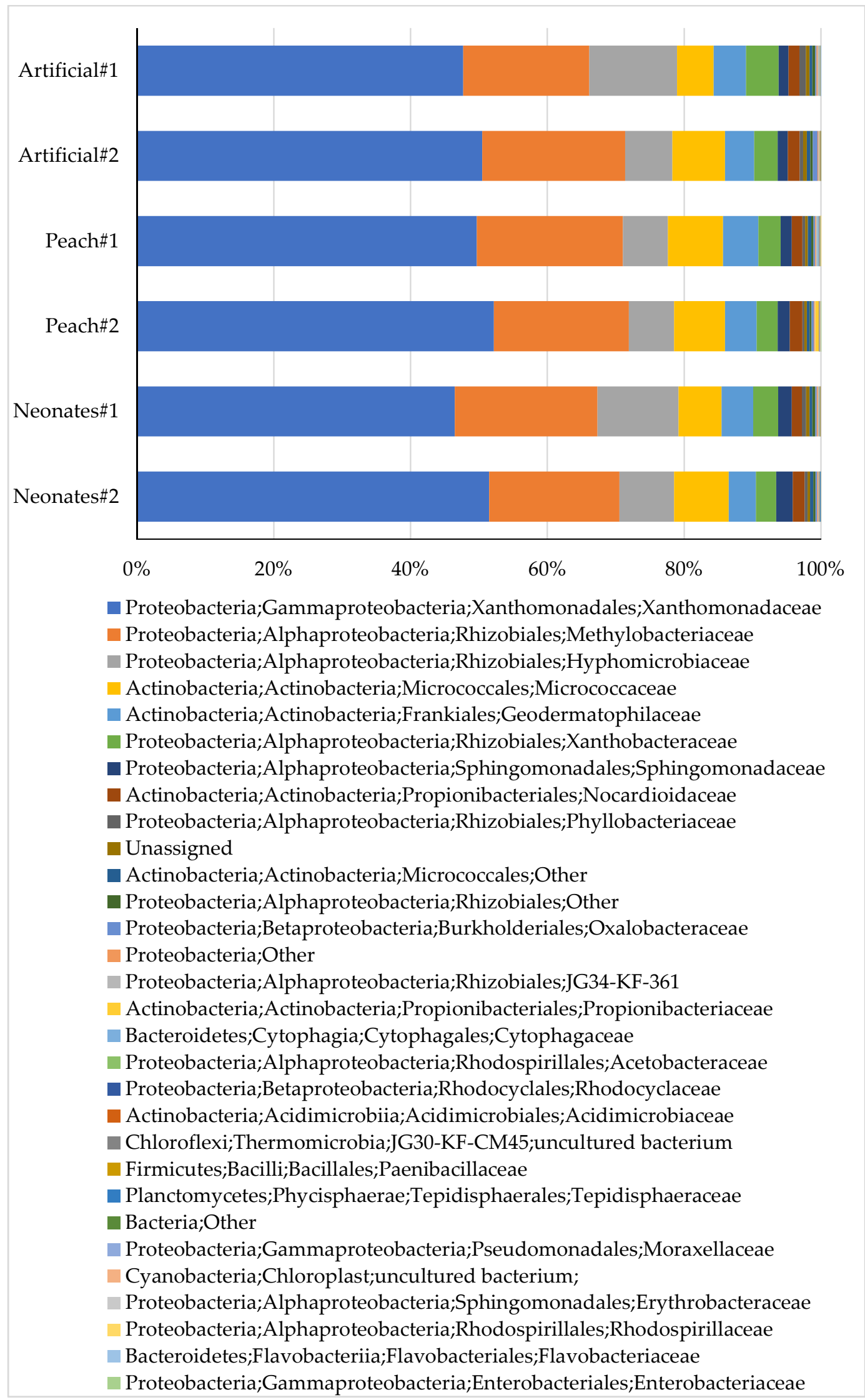

Figure 3. Taxonomy assignment at the family level of $C$. tenebrionis on three different feeding regimes. 
The most abundant (ca. 50\%) reads were affiliated with the Xanthomonadaceae family within the Gammaproteobacteria class (Figure 3), where $45 \%$ of them were not identified at the genus level using the Silva database as a reference. Blastn analysis (https:/ /blast.ncbi.nlm.nih.gov/Blast.cgi), however, revealed that these reads are affiliated with genus Lysobacter, members of which are Gram negatives widely distributed in soil, plant, and freshwater habitats. Reads affiliated with Lysobacter were one of the most prevalent groups in the gut flora of herbivorous cephalotine ants (Cephalotes varians, C. rohweri, and C. atratus) [13]. Cellulase and glucanase activities [14] were identified in some Lysobacter species: IB-9374 [15], L. capsici AZ78 [16], and L. enzymogenes strain N4-7 [17]. Moreover, L. enzymogenes controls phytopathogenic nematodes [18] and fungi such as Bipolaris sorokiniana [19], Uromyces appendiculatus [20], Fusarium graminearum [21], and Rhizoctonia solani [22]. Lysobacter gummosus that lives on redback salamanders' skin produces 2,4-diacetylphloroglucinol, which inhibits the growth of certain pathogenic fungi [23].

The second most abundant (ca. 20\%) reads are affiliated with the Methylobacteriaceae family (order Rhizobiales, class Alphaproteobacteria) (Figure 3). The blastn revealed that 91\% (ca. 65\%, similarity cut-off $96 \% ; 26 \%$, similarity cut-off $97 \%$ ) of the all Methylobacteriaceae are affiliated with genus Microvirga, $7.5 \%$ are classified as genus Methylobacterium, and the rest (about 1.5\% reads) were identified as uncultured Methylobacteriaceae.

The Microvirga (formerly Balneimonas) and Methylobacterium species are ubiquitous in nature, mainly soil and water, but also plants' phylloplane [24-26]. Bacteria of the Microvirga and Methylobacterium genera have recently been found essential for efficient digestion of lignocellulose in the gut of the wood-feeding termite Reticulitermes chinensis (Isoptera: Rhinotermitidae) [27], that digest glucosyl and xylosyl residues from lignocellulose [28]. Methylobacterium spp. perform lipolytic activity in weevils (Coleoptera: Curculionidae) and may play a role in nutritional processes [29]. The abundance (ca. 20\%) of Microvirga and Methylobacterium in C. tenebrionis may therefore be involved in cellulolytic and lipolytic activities.

The third most abundant (ca. 9\%) reads are affiliated with the Hyphomicrobiaceae family within the Alphaproteobacteria class (Figure 3). Analysis by blastn classified them to the genus Devosia (similarity cut-off $96 \%$ ). Cellulolytic bacteria belonging to this genus were isolated from the larval gut of root-feeding Holotrichia parallela (Coleoptera: Scarabaeidae) [30] and of silkworm [31]. It is reasonable that the flat-headed root borer $C$. tenebrionis harbors these cellulolytic bacteria.

The fourth most abundant $(7 \%)$ reads are affiliated with the Micrococcaceae family (class Actinobacteria) (Figure 3). Analysis by blastn affiliated most of them with the Gram-positive coryneform genus Arthrobacter (similarity cut-off $97 \%$ ), members of which are commonly found in soil. Arthrobacter gandensis and A. gandavensis were isolated from the wireworm Agriotes lineatus (L.) (Coleoptera: Elateridae), a serious pest of various vegetables and fruits throughout the world [32]. Arthrobacter pityocampae was isolated from the pine processionary moth Thaumetopoea pityocampa (Lepidoptera: Thaumetopoidae), one of the most harmful pests of pine species in Mediterranean countries [33]. Arthrobacter ssp. are prevalent in the gut microbiota of the cave beetles Neobathyscia pasai and N. mancinii (Coleoptera: Leiodidae) [34]. Wood-digesting Arthrobacter sp., which had been isolated from the hind-gut of the termite Reticulitermes hesperus [35], was also found in the microbiome of C. tenebrionis.

The fifth most abundant (4.5\%) reads are affiliated with the Geodermatophilaceae family (order Actinomycetales) (Figure 3). Analysis by blastn affiliated most of them with the genus Blastococcus (similarity cut-off $97 \%$ ). Members of the family Geodermatophilaceae contain bacteria isolated mainly from soils, seawater, and stone surfaces [36]. Little is known about Blastococcus, but reads belonging to this genus have been retrieved from globally important pest, the chilli thrips Scirtothrips dorsalis (Thysanoptera: Thripidae) [37] and strains affiliated with Geodermatophilus, were found associated with Paratrechina longicornis (Hymenoptera: Formicidae) [38].

Apart from habitat- and diet-specific microbes, an insect's gut harbors a core microbiome, members of which have likely co-evolved with the host and fulfill important functions, such as 
cellulose degradation [39], breakdown of ingested toxins, or overcome chemicals used for insect control $[6,40,41]$. Indigenous bacteria are often specialized gut symbionts and are transmitted vertically from the eggs, through coprophagy or social interactions. Gut communities of social insects are usually more distinctive and consistent than those of non-social invertebrates [6]. The findings described here reveal a high similarity of microbial communities retrieved from C. tenebrionis neonates (hatching larvae before any act of feeding) or reared on either peach plants or an artificial diet. These findings imply that the larvae acquire much of their bacterial biome from the parent adult.

Gut symbionts may have the potential to protect their host from insecticides such as fenitrothion [40]. In gypsy moth larvae, on the other hand, elimination of the indigenous midgut microbial community abolished insecticidal activity of Cry's, and re-introduction of a specific member of this community restored Bacillus thuringiensis-mediated killing [42]. Bacterial symbionts may be utilized to manage insect pests [6] in different ways: insecticidal potential of entomopathogenic gut bacteria may serve for pest management; genetically modified bacteria can be used as vehicles to specifically express foreign traits that interfere fitness of the pest; gut symbiont that naturally inhibit parasite colonization could be disseminated in insect populations, for example, to prevent spread of human disease via insect vectors or influence vector competence by modulating immune responses. Characterizing the core microbiota of $C$. tenebrionis larvae is essential for understanding their physiology and ecology, and thus could be helpful in developing the next generation of pest control strategies.

\section{Materials and Methods}

Adults of $C$. tenebrionis were collected in nectarine orchard next to Yesod HaMa'ala (Hulla Valley, $33^{\circ} 05^{\prime} 26^{\prime \prime} \mathrm{N}, 35^{\circ} 58^{\prime} 90^{\prime \prime} \mathrm{E}$, and newly-hatched larvae of the first lab generation were examined. Larvae were randomly sampled from hatching neonates, and from individuals lab-reared on peach plants and on an artificial diet over four weeks [43]. The larvae were surface-sterilized with $75 \%$ ethanol for $90 \mathrm{~s}$, rinsed twice with sterilized-deionized water, and stored at $-80^{\circ} \mathrm{C}$.

Total bacterial DNA was extracted from the larvae using the PowerSoil ${ }^{\circledR}$ DNA Isolation Kit (MO BIO laboratories, San Diego, CA, USA) following the manufacturer's protocol, except that each sample was placed into liquid nitrogen and crushed with a pestle before cell lysis. Total genomic DNA extraction of 6 samples, each composed of 3 C. tenebrionis larvae, was performed by the DNA Services Facility at the Research Resources Center, at the University of Illinois at Chicago, for $16 \mathrm{~S}$ rRNA gene sequencing using the Illumina MiSeq platform. Conserved regions V1-V3 of the 16S rDNA were amplified using PCR with the pair of primers CS1_27F/CS2_534R. A total of 1,056,756 reads were obtained.

Raw reads were merged using the software package PEAR (v0.9.10) [44]. Low quality sequences and chimeras were removed by the software package Mothur (v1.36.1) [45]. The quality-controlled sequences were processed with the Quantitative Insights into Microbial Ecology (QIIME v1.9.1) package [46]. Briefly, sequence data were clustered into operational taxonomic units (OTU) at 97\% similarity using UCLUST. Representative sequences from each OTU were extracted and aligned using PyNAST with a percent identity threshold of $60 \%$ to the Silva 16S rRNA bacterial database [47]. Representative sequences were classified for taxonomy assignment by UCLUST and Silva database. Unassigned OTUs at the genus level were analyzed using standard nucleotide BLAST analysis (https: / / blast.ncbi.nlm.nih.gov / Blast.cgi). A Biological Observation Matrix (BIOM) was generated at different taxonomic levels. OTU with a total observation count lower than 50 reads were discarded. Qiime was also used to generate an alpha rarefaction plot as well as principal coordinate analysis (PCoA) plots based on weighted and unweighted UniFrac metrics (beta diversity).

Author Contributions: A.K., Z.M., D.M., and E.B.-D. conceived the study; P.K. extracted total bacterial DNA; H.B. and E.B.-D. analyzed the data; E.B.-D., H.B., and A.Z. wrote the paper. All authors read and approved the final manuscript. 
Funding: This study was supported by Grant \# 857-0684-13 of the Chief Scientist, Israel Ministry of Agriculture (to A.K., Z.M., E.B.-D., and A.Z.). Scholarship (for P.K.) from the Council for Higher Education (VATAT) of Israel.

Conflicts of Interest: The authors declare no conflict of interest.

\section{References}

1. Chornesky, E.A.; Bartuska, A.M.; Aplet, G.H.; Britton, K.O.; Cummings-Carlson, J.; Davis, F.W.; Eskow, J.; Gordon, D.R.; Gottschalk, K.W.; Haack, R.A.; et al. Science priorities for reducing the threat of invasive species to sustainable forestry. AIBS Bull. 2005, 55, 335-348. [CrossRef]

2. Vasanthakumar, A.; Handelsman, J.O.; Schloss, P.D.; Bauer, L.S.; Raffa, K.F. Gut microbiota of an invasive subcortical beetle, Agrilus planipennis Fairmaire, across various life stages. Environ. Entomol. 2008, 37, 1344-1353. [CrossRef] [PubMed]

3. Schloss, P.D.; Delalibera, I., Jr.; Handelsman, J.O.; Raffa, K.F. Bacteria associated with the guts of two wood boring beetles: Anoplophora glabripennis and Saperda vestita (Cerambycidae). Environ. Entomol. 2006, 35, 625-629. [CrossRef]

4. Vasanthakumar, A.; Delalibera, I., Jr.; Handelsman, J.; Klepzig, K.D.; Schloss, P.D.; Raffa, K.F. Characterization of gut-associated bacteria in larvae and adults of the southern pine beetle, Dendroctonus frontalis Zimmermann. Environ. Entomol. 2006, 35, 1710-1717. [CrossRef]

5. Douglas, A.E. The microbial dimension in insect nutritional ecology. Funct. Ecol. 2009, 23, 38-47. [CrossRef]

6. Engel, P.; Moran, N.A. The gut microbiota of insects-Diversity in structure and function. FEMS Microbiol. Rev. 2016, 37, 699-735. [CrossRef]

7. Welte, C.U.; de Graaf, R.M.; van den Bosch, T.J.; Op den Camp, H.J.; van Dam, N.M.; Jetten, M.S. Plasmids from the gut microbiome of cabbage root fly larvae encode SaxA that catalyzes the conversion of the plant toxin 2-phenylethyl isothiocyanate. Environ. Microbiol. 2016, 18, 1379-1390. [CrossRef]

8. Hammer, T.J.; Bowers, M.D. Gut microbes may facilitate insect herbivory of chemically defended plants. Oecologia 2015, 179, 1-14. [CrossRef]

9. Berasategui, A.; Salem, H.; Paetz, C.; Santoro, M.; Gershenzon, J.; Kaltenpoth, M.; Schmidt, A. Gut microbiota of the pine weevil degrades conifer diterpenes and increases insect fitness. Mol. Ecol. 2017, 26, 4099-4110. [CrossRef]

10. Ben-Yehuda, S.; Assael, F.; Mendel, Z. Improved chemical control of Capnodis tenebrionis L. and C. carbonaria Klug (Coleoptera: Buprestidae) in stone-fruit plantations in Israel. Phytoparasitica 2000, 28, 27-41. [CrossRef]

11. Gindin, G.; Mendel, Z.; Levitin, B.; Kumar, P.; Levi, T.; Shahi, P.; Khasdan, V.; Weinthal, D.; Kuznetsova, T.; Einav, M.; et al. The basis for rootstock resilient to Capnodis species: Screening for genes encoding $\delta$-endotoxins from Bacillus thuringiensis. Pest Manag. Sci. 2014, 70, 1283-1290. [CrossRef] [PubMed]

12. Strano, C.P.; Malacrinò, A.; Campolo, O.; Palmeri, V. Influence of host plant on Thaumetopoea pityocampa gut bacterial community. Microb. Ecol. 2018, 75, 487-494. [CrossRef] [PubMed]

13. Anderson, K.E.; Russell, J.A.; Moreau, C.S.; Kautz, S.; Sullam, K.E.; Hu, Y.I.; Basinger, U.; Mott, B.M.; Buck, N.; Wheeler, D.E. Highly similar microbial communities are shared among related and trophically similar ant species. Mol. Ecol. 2012, 21, 2282-2296. [CrossRef] [PubMed]

14. Gómez Expósito, R.; Postma, J.; Raaijmakers, J.M.; De Bruijn, I. Diversity and activity of Lysobacter species from disease suppressive soils. Front. Microbiol. 2015, 6, 1243. [CrossRef]

15. Ogura, J.; Toyoda, A.; Kurosawa, T.; Chong, A.L.; Chohnan, S.; Masaki, T. Purification, characterization, and gene analysis of cellulase (Cel8A) from Lysobacter sp. IB-9374. Biosci. Biotechnol. Biochem. 2006, 70, 2420-2428. [CrossRef]

16. Puopolo, G.; Tomada, S.; Sonego, P.; Moretto, M.; Engelen, K.; Perazzolli, M.; Pertot, I. The Lysobacter capsici AZ78 genome has a gene pool enabling it to interact successfully with phytopathogenic microorganisms and environmental factors. Front. Microbiol. 2016, 7, 96. [CrossRef]

17. Palumbo, J.D.; Sullivan, R.F.; Kobayashi, D.Y. Molecular characterization and expression in Escherichia coli of three $\beta$-1,3-glucanase genes from Lysobacter enzymogenes strain N4-7. J. Bacteriol. 2003, 185, 4362-4370. [CrossRef]

18. Chen, J.; Moore, W.H.; Yuen, G.Y.; Kobayashi, D.; Caswell-Chen, E.P. Influence of Lysobacter enzymogenes strain C3 on nematodes. J. Nematol. 2006, 38, 233-239. 
19. Zhang, Z.; Yuen, G.Y. Biological control of Bipolaris sorakiniana on tall fescue by Stenotrophomonas maltophilia strain C3. Phytopathology 1999, 89, 817-822. [CrossRef]

20. Yuen, G.Y.; Steadman, J.R.; Lindgren, D.T.; Schaff, D.; Jochum, C. Bean rust biological control using bacterial agents. Crop Prot. 2001, 20, 395-402. [CrossRef]

21. Jochum, C.C.; Osborne, L.E.; Yuen, G.Y. Fusarium head blight biological control with Lysobacter enzymogenes. Biol. Control 2006, 39, 336-344. [CrossRef]

22. Postma, J.; Schilder, M.T.; Bloem, J.; Van Leeuwen-Haagsma, W.K. Soil suppressiveness and functional diversity of the soil microflora in organic farming systems. Soil Biol. Biochem. 2008, 40, 2394-2406. [CrossRef]

23. Brucker, R.M.; Baylor, C.M.; Walters, R.L.; Lauer, A.; Harris, R.N.; Minbiole, K.P.C. The identification of 2,4-diacetylphloroglucinol as an antifungal metabolite produced by cutaneous bacteria of the salamander Plethodon cinereus. J. Chem. Ecol. 2008, 34, 39-43. [CrossRef] [PubMed]

24. Kelly, D.P.; McDonald, I.R.; Wood, A.P. The family Methylobacteriaceae. In The Prokaryotes; Springer: Berlin/Heidelberg, Germany, 2014; pp. 313-340.

25. Liu, Y.H.; Guo, J.W.; Salam, N.; Li, L.; Zhang, Y.G.; Han, J.; Mohamad, O.A.; Li, W.J. Culturable endophytic bacteria associated with medicinal plant Ferula songorica: Molecular phylogeny, distribution and screening for industrially important traits. 3 Biotech 2016, 6, 209. [CrossRef] [PubMed]

26. Msaddak, A.; Duran, D.; Rejili, M.; Mars, M.; Argueso, T.R.; Imperial, J.; Palacios, J.; Rey, L. Diverse bacteria affiliated with the genera Microvirga, Phyllobacterium, and Bradyrhizobium nodulate Lupinus micranthus growing in soils of Northern Tunisia. Appl. Environ. Microbiol. 2017, 83. [CrossRef]

27. Zhou, N.; Sun, Y.T.; Chen, D.W.; Du, W.; Yang, H.; Liu, S.J. Harnessing microfluidic streak plate technique to investigate the gut microbiome of Reticulitermes chinensis. MicrobiologyOpen 2018, e00654. [CrossRef]

28. Bignell, D.E. Morphology, physiology, biochemistry and functional design of the termite gut: An evolutionary wonderland. In Biology of Termites: A Modern Synthesis; Bignell, D.E., Roisin, Y., Lo, N., Eds.; Springer: Dordrecht, The Netherlands, 2011; pp. 375-412.

29. Setiawan, R.; Sumerta, I.N.; Anita, S.; Narakusumo, R.P. Isolation and Enzymatic Activities of Bacteria Associated to Weevils (Coleoptera: Curculionidae). In Proceedings of the 4th International Symposium on Innovative Bioproduction, Bogor, Indonesia, 27 September 2017; pp. 39-47.

30. Huang, S.; Sheng, P.; Zhang, H. Isolation and identification of cellulolytic bacteria from the gut of Holotrichia parallela larvae (Coleoptera: Scarabaeidae). Int. J. Mol. Sci. 2012, 13, 2563-2577. [CrossRef]

31. Liang, X.; Fu, Y.; Tong, L.; Liu, H. Microbial shifts of the silkworm larval gut in response to lettuce leaf feeding. Appl. Microbiol. Biotechnol. 2014, 98, 3769-3776. [CrossRef]

32. Danismazoglu, M.; Demir, İ.; Sevim, A.; Demirbag, Z.; Nalcacioglu, R. An investigation on the bacterial flora of Agriotes lineatus (Coleoptera: Elateridae) and pathogenicity of the flora members. Crop Prot. 2012, 40, 1-7. [CrossRef]

33. Ince, I.A.; Demirbağ, Z.; Kati, H. Arthrobacter pityocampae sp. nov., isolated from Thaumetopoea pityocampa (Lep., Thaumetopoeidae). Int. J. Syst. Evol. Microbiol. 2014, 64, 3384-3389. [CrossRef]

34. Latella, L.; Castioni, A.; Bignotto, L.; Salvetti, E.; Torriani, S.; Felis, G.E. Exploring gut microbiota composition of the cave beetles Neobathyscia pasai Ruffo, 1950 and Neobathyscia mancinii Jeannel, 1924 (Leiodidae; Cholevinae). Boll. Mus. Civ. Stor. Nat. Verona 2017, 41, 3-24.

35. Thayer, D.W. Facultative wood-digesting bacteria from the hind-gut of the termite Reticulitermes hesperus. J. Gen. Microbiol. 1976, 95, 287-296. [CrossRef] [PubMed]

36. Normand, P.; Daffonchio, D.; Gtari, M. The Family Geodermatophilaceae. In The Prokaryotes; Rosenberg, E., DeLong, E.F., Lory, S., Stackebrandt, E., Thompson, F., Eds.; Springer: Berlin/Heidelberg, Germany, 2014.

37. Dickey, A.M.; Trease, A.J.; Jara-Cavieres, A.; Kumar, V.; Christenson, M.K.; Potluri, L.P.; Morgan, J.K.; Shatters, R.G., Jr.; Mckenzie, C.L.; Davis, P.H.; et al. Estimating bacterial diversity in Scirtothrips dorsalis (Thysanoptera: Thripidae) via next generation sequencing. Fla. Entomol. 2014, 97, 362-366. [CrossRef] [PubMed]

38. Reyes, R.D.; Cafaro, M.J. Paratrechina longicornis ants in a tropical dry forest harbor specific Actinobacteria diversity. J. Basic Microbiol. 2015, 55, 11-21. [CrossRef] [PubMed]

39. Warnecke, F.; Luginbühl, P.; Ivanova, N.; Ghassemian, M.; Richardson, T.H.; Stege, J.T.; Cayouette, M.; McHardy, A.C.; Djordjevic, G.; Aboushadi, N.; et al. Metagenomic and functional analysis of hindgut microbiota of a wood-feeding higher termite. Nature 2007, 450, 560-565. [CrossRef] 
40. Kikuchi, Y.; Hayatsu, M.; Hosokawa, T.; Nagayama, A.; Tago, K.; Fukatsu, T. Symbiont-mediated insecticide resistance. Proc. Natl. Acad. Sci. USA 2012, 109, 8618-8622. [CrossRef] [PubMed]

41. Ping, L.; Büchler, R.; Mithöfer, A.; Svatoš, A.; Spiteller, D.; Dettner, K.; Gmeiner, S.; Piel, J.; Schlott, B.; Boland, W. A novel Dps-type protein from insect gut bacteria catalyses hydrolysis and synthesis of N-acyl amino acids. Environ. Microbiol. 2007, 9, 1572-1583. [CrossRef] [PubMed]

42. Broderick, N.A.; Robinson, C.J.; McMahon, M.D.; Holt, J.; Handelsman, J.; Raffa, K.F. Contributions of gut bacteria to Bacillus thuringiensis-induced mortality vary across a range of Lepidoptera. BMC Biol. 2009, 7, 11. [CrossRef]

43. Gindin, G.; Kuznetsowa, T.; Protasov, A.; Ben-Yehuda, S.; Mendel, Z. Artificial diet for two flat headed borers, Capnodis spp. (Coleoptera: Buprestidae). Eur. J. Entomol. 2009, 106, 573-581. [CrossRef]

44. Zhang, J.; Kobert, K.; Flouri, T.; Stamatakis, A. PEAR: A fast and accurate Illumina Paired-End reAd mergeR. Bioinformatics 2014, 30, 614-620. [CrossRef] [PubMed]

45. Schloss, P.D.; Westcott, S.L.; Ryabin, T.; Hall, J.R.; Hartmann, M.; Hollister, E.B.; Lesniewski, R.A.; Oakley, B.B.; Parks, D.H.; Robinson, C.J.; et al. Introducing mothur: Open-source, platform-independent, community supported software for describing and comparing microbial communities. Appl. Environ. Microbiol. 2009, 75, 7537-7541. [CrossRef] [PubMed]

46. Caporaso, J.G.; Kuczynski, J.; Stombaugh, J.; Bittinger, K.; Bushman, F.D.; Costello, E.K.; Fierer, N.; Pena, A.G.; Goodrich, J.K.; Gordon, J.I.; et al. QIIME allows analysis of high-throughput community sequencing data. Nat. Methods 2010, 7, 335-336. [CrossRef] [PubMed]

47. Quast, C.; Pruesse, E.; Yilmaz, P.; Gerken, J.; Schweer, T.; Yarza, P.; Peplies, J.; Glöckner, F.O. The SILVA ribosomal RNA gene database project: Improved data processing and web-based tools. Nucleic Acids Res. 2013, 41, D590-D596. [CrossRef] [PubMed]

(C) 2019 by the authors. Licensee MDPI, Basel, Switzerland. This article is an open access article distributed under the terms and conditions of the Creative Commons Attribution (CC BY) license (http:/ / creativecommons.org/licenses/by/4.0/). 